\title{
Spiritual Gullibility in Search of Health: Tragedies of Scarcity and Sanctity in African Contexts
}

\section{Peter Maiko Mageto}

\begin{abstract}
The premise of this article is that health faces tragedies nowadays that are more economic and social rather than medical. Sanctity provides an understanding that all human beings, no matter the condition of their bodies, are created in the image of God. Hence, the value of each life makes us all, equal. In this article, I use the term 'tragedies', because sanctity and scarcity are defined with a collaborative thought as people tell sad stories of their bodies, as they are unable to attend to them economically or socially. In this article, Faith Healing Ethics reminds us that when sanctity and scarcity collaborate, what is at stake is the issue of identity, character and virtue in the search for health. Indeed, the sanctity of ensuring holistic health of our bodies (which this article focuses on), is undermined by the gullibility of economic and social scarcity of our time that the search for health demands. Gullibility then sways human beings who seek health with regard to sanctity of their being and the scarcity of their resources. Yet, scarcity remains a tragedy, as gullible spiritualists exploit the poor whose financial capability is so limited that many succumb to their illness. Faith healing ethics reminds us that we must hold the two tragedies (sanctity and scarcity) together to ensure that gullibility regarding health within an African context does not undermine those seeking faith healing.
\end{abstract}

Keywords: Gullibility, health, scarcity, sanctity, faith healing

\section{Introduction}

African contexts are multifaceted with tremendous opportunities and disasters at the same time. Whether it is such experiences as the Seven Wonders of the 
World like the Victoria Falls of Zimbabwe, or Kenya's Maasai Mara Reserve, or natural disasters like Cyclone Idai or the global COVID-19 pandemic, one thing is clear: to be poor is to be preyed upon by those in power, and often the poor lack choices. However, the COVID-19 pandemic continues to reveal to us that spiritual gullibility is being played upon many innocent people due to two striking tragedies in Africa, namely scarcity and sanctity. The majority of the African people continue to present with myriad challenges, some indeed stemming from colonial and post-colonial tendencies. Mageto (2006) argues,

Colonial and missionary scrambles made sure that conquering for Christ was perpetuated through the introduction of new languages, science, geography and history by ensuring that everything related to healing, whether it is the use of herbs and roots were demonized and eliminated from the African worldview.

This conquering seems to set a pattern, as the post-colonial and neo-colonial missionary seems to be perpetuating spiritual gullibility largely. Unfortunately, those in search of health, who are the poor majority, face quite dehumanizing and belittling conditions that are enhanced by structural and inhumane systems that have locked them out of any meaningful health services. Those in search of health often feel exhausted, disgusted, and worthless when services are not easily accessible and as spiritual gullibility becomes an easy option. All people created in the image of God must be protected from any infuriating intolerance and indifference. There is a need to listen keenly to both verbal and non-verbal communication as we seek to engage every person to ensure that in their search for health services, they are not preyed upon between structural systems and spiritual gullibility.

\section{Terms Defined}

One way to understand every context is to appreciate the use of terms. In this article, different terms are defined to provide the foundation for the argument developed. Health is defined by the World Health Organization (1998:1) as 'a state of complete physical, mental and social well-being and not merely the absence of disease or infirmity'. However, there have been recent criticisms over this definition regarding its limitations, as it negates the 'spiritual' dimension of well-being. Hence the need to understand health holistically as 


\section{Peter Maiko Mageto}

derived from God the creator of life/humanity. Therefore, ill-health is anything that hinders humanity from attaining its full potential. Consequently, for the purpose of this article, I argue that health can be understood from the various languages that our people in the continent use to speak of health. For many communities health may mean no injury. In other words, it may be that if disaster occurs, whether natural, it does not touch a person's well-being when understood holistically. Secondly, health may mean a person's capacity to cope with relations, and herein may be relations amongst human beings, or relations with their belongings. In other words, how well a person's relations are nurtured, and how well the person has nurtured those of his or her household, and such belongings as land, animals, etc. Thirdly, health in some communities refers to one's relationship with God or gods, as manifested in the manner in which an individual balances daily living within society, the environment, and all that pertains to his or her well-being. Such a person is understood to being almost in agreement with everything provided he or she does not foresee evidence of negative disturbance. This kind of understanding of health surpasses the confinement of health definitions to the physical state which all in healthcare and in spiritual circles aim to achieve.

While health may encompass different definitions, tragedy is understood to mean causing suffering, distress, loss or failure. Keep in mind that in traditional settings, ailment or misfortune was dealt with through the role of medicine-men, soothsayers, traditional healers, and other divinities. Mageto (2006: 20) argues that the aim was 'to subjugate disease and restore the wellbeing of the individual and community'. However, it is also important to note that Africans also held the belief that there was a power in witchcraft. Kunhiyop (2008: 378) argues that, 'belief in witchcraft thus serves a very practical purpose in explaining events and the causes behind them'. In search of things that compliment health, we think of such belief as the practice of witchcraft, a belief endorsed by some people even in the $21^{\text {st }}$ century. In African societies witchcraft is 'a family logical device' (Bohannan 1964: 232); 'a mysterious power' (Haule 1969: 21); or 'part of the mystery of the human person' (Magesa 1997: 181). Tragedy as a basis of worry in spiritual gullibility is underscored for the reader to see the struggle that individuals face in making decisions while faced with spiritual gullibility. In essence, tragedy in this article is developed to show that those who engage in spiritual gullibility create stress to heighten the suffering of the poor in order to compel them to worry about loss or failure to engage in spiritual gullibility. 
Another term utilized in this article is sanctity. Sanctity, derived from the Latin term sanctum, points to a state of being sacred, goodness or quality of being holy. Sanctity then means that we have to consider it from two angles: bios (biological life) or zoê (spiritual life). The essence of sanctity is when both bios and zoe are seamlessly embraced, otherwise the agents of spiritual gullibility will be playing one against the other. In health, sanctity generally almost speaks to what we, as the African people, have come to embrace as Ubuntuism, which is the essence of treating life as sacred, which requires honour, respect, and sacrifice to keep it so. In Christianity, it is treating human life as an image of God. Sanctity via Ubuntuism demands that everything must be done to ensure that the health and well-being of each individual in the family or community is protected from any tragedies of life, no matter his or her status or condition. Yet, the tragedy of sanctity refers to all the moral problems that human beings face pertaining to protecting, defending and respecting human life.

Finally, scarcity is understood to mean the pressure that demand in the market places on human beings over the availability of a given commodity or service. In many African communities, this is embraced as shortage or poverty. However, it is critical to keep in mind that in some situations scarcity can be real; it can be engineered; it can be imagined; and it can inculcated. This is a danger when spiritual gullibility is played on the innocent. It can also be pressed down to the weak in society through corruption and other practices that deny justice and mercy as a means of grace and service. In this article, by scarcity I do not mean the given or natural limits, resources or shortages wrought by excessive consumption of those resources.

\section{Contextualizing 'In search of Health'}

All people desire to be in good health. In everything they do or imagine, their main pointer is to be and remain in good health. Yet, within the African context as we know it today, with the presence of the COVID-19 global pandemic, the malaria menace, and the HIV and AIDS burden, the people on the continent have not stopped searching for health and well-being in whatever form this may be attained. In contextualizing 'In search of health' we cherish all peoples who join their efforts, even in their scarcity, to support one another in ensuring that the sanctity of life is sustained. Within an African traditional setting, Omonzejele (2008: 120) has set the context 'in search of health' by putting it this way, 
For the traditional African, health is not just about the proper functioning of bodily organs. Good health for the African consists of mental, physical, spiritual and emotional stability (of) oneself, family members, and community. Good health for an African is not a subjective affair). Good health is usually understood in terms of relationship with one's ancestors, and therefore not just confined on how the living are affected, but also the ancestors. It also entails appropriate behavior that is enshrined in the values and norms of society.

In other words, the health of an African is the health of everyone. If a parent is unwell, everyone in that household is unwell. Good health is divinely and humanely linked. It is the familiar web that ensures the sharing of the sanctity of life while thwarting all the tragedies of life. This is why John Mbiti (1969: 108-109), writes,

Whatever happens to the individual happens to the whole group, and whatever happens to (the) whole group happens to the individual. The individual can only say: I am because we are, and since we are, therefore I am.

Matters of health are not an exception to this philosophy, as 'the spirit of solidarity and interdependence gave Africans a sense of the family, community, solidarity and participation, for life is celebrated as the most valued of relationships among God's creation' (Mageto 2006: 4). However, spiritual gullibility has made some individuals to negate the Ubuntu values and only seek to enrich themselves. Indeed, Mbiti and Mageto's observations above affirm the fact that for an African, scarcity and sanctity should be noted, but not be allowed to destroy a life or the well-being of any member of society. Therefore, spiritual gullibility would be understood as a misnomer and a foreign entrant to exploit the innocent.

The social fabric that ensures and assures an Africa's 'we are' is made stronger in the words of the World Health Organization in acknowledging the importance of indigenous healthcare by observing 'the total combination of knowledge and practice, whether explicable or not used in diagnosing, preventing or eliminating physically, mental and social diseases' (WHO 2001: 1). In an African setting of COVID-19 and other health-related challenges, healthcare, as intertwined with cultural and religious beliefs, is considered 
holistic by nature. Its focus is beyond the physical condition , as it includes psychological, spiritual and social aspects of individuals, families and communities. The well-being of each individual's well-being is so critical that nothing or no-one can be separated from another. This is why celebrating indigenous knowledge and practices within the realm of health, does not negate the spiritual connotations that are likely to arise from such contexts at all, since indigenous healing may take place; hence, the need to engage the contexts from which potential spiritual gullibility may stem.

Often, we feel healthy, but that does not mean that medical professionals will not declare the presence of disease tomorrow. We can only be guard, because the absence of disease today does not guarantee a clean bill of health tomorrow. It is for this reason that even those who face no disease today, also fall into the spiritual gullibility trap, because the inner conviction is that one must guard one's health against tomorrow's hazardous attacks on our health. For this reason, the presence of symptoms of illness may also provide avenues for spiritual gullibility. However, more challenging is whether individuals have created a circle of relational equilibrium to ensure their wellbeing is not manipulated, exploited or negated.

From the above discussions, spiritual gullibility is a potential that occurs a lot in healthcare settings. The aim is not providing a permanent solution to the health of the person, but that the conditions of scarcity and scarcity propel the perpetrators and the victim to participate in such undertakings. More often, the aim is material or a financial gain and not necessarily to alleviate the disease. Those engaged in spiritual gullibility have no time to explore various alternatives that professional medics would undertake based on the tragedies of scarcity and scarcity.

Karl Barth (1998: 155) argued that,

What matters is not something but someone, the real man before God and among his fellows, his individual psycho/physical existence, his movement in time, his freedom, his orientation to God and solidarity with others.

\section{Situating the Tragedy of Sanctity}

Advances in medical science and technology are serving the good of life, depending on various factors. These advances have confronted us with new 
alternatives of choice between life and death. Such alternatives include, but are not limited to choosing to save a potentially defective foetus; choosing to keep the terminally ill alive through technology; innovating new technologies to offer services to those who can afford it, while the poor remain relegated to more suffering; investing in research on those diseases that the rich suffer from, while little is done to address systemic structural traps that continue to trap the vulnerable in our countries. Take note that these developments, through globalization, have also opened an avenue for other avenues for expressing spiritual gullibility explicitly However, these questions have also opened an avenue for alternative healing through which spiritual gullibility is practised. When people attempt to take that responsibility seriously, they are faced with choices of life or death; hence the question on the sanctity of life.

All people are created in the image of God. Therefore, at every given stage, from birth to natural death, the sanctity of life, whether the unborn children or the elderly, no-one should be exploited marginalized or exploited. All measures must be taken to defend, protect and value the sanctity of life. Life is God's gift to humanity, thus ill-health does not diminish the value of any life. For this reason, those who engage in spiritual gullibility must be stopped! This is why I call sanctity a tragedy, since among us we have those who have engineered spiritual gullibility to exploit others and we are unable to defend protect and value all human life. Sanctity demands that we conceptualize all human beings in any and every state be viewed and treated as God's image. While spiritual gullibility will exploit classism, social status, economic gain, gender, religions and even ethnicity or race, we must remain focused in order not to allow the sanctity of life to be diminished.

There are two biblical texts that indeed help us to see sanctity as a call to defend, protect and respect human life. In Genesis 1: 17, the text establishes that human life is sacred, for to be created in the likeness (image) of God, meaning that each human being bears His image. This is a privileged status reserved only to humankind. Then, we have Psalm 139: 14, which establishes that we are 'fearfully and wonderfully made', some kind of creative work from womb to the regeneration of cells and tissue for the body's healing; we can only testify to the evidence of God's own work. However, the tragedy of sanctity comes at the forefront, because it is the original intent of sanctity to ensure the dignity of human life that has not been established or kept and this should drive our understanding of national healthcare; not capitalist or socialist approaches. 
Sanctity surpasses ethnicity, gender, race, age or location. Sanctity surpasses the local congregations where most of the spiritual gullibility activities take place. Sanctity sends an alarm where humanity may be going wrong in treating others with impunity or exploitation. Sanctity demands that all people, men and women, young and old be treated with dignity, regardless of their physical, social or economic status in society.

Sanctity calls us to care for and bear one another. In search of health, sanctity becomes a tragedy, as the sick, the disabled, and the vulnerable are a burden to those who have to care for them. The tragedy of sanctity stares us at the face in times of dependence and need. This tragedy is made even worse when we remove God from the scene of our suffering, forgetting that $\mathrm{He}$ is sovereign over the affairs of our lives, including our frailty and infirmity. Those who hide in spirituality and prey upon their adherents with ignorance and misinformation regarding their health, fail to honour Proverbs 31: 8, 'Speak out for those who cannot speak, for the rights of all the destitute'. Sanctity demands that we value the life of the other as sacred and do whatever it takes to ensure that we become their mouthpieces in highlighting their rights and potential abuse that they face.

Often, many seeking spiritual refuge when they are in search of health. Many are knocking at the doors of sacred practitioners as they seek divine intervention. Unfortunately, it is such people who end up becoming trapped in spiritual gullibility, as often prayers for sale are pronounced, excessive spiritual activities engagements are demanded, or tithes are commanded to unleash spiritual blessings for healing and prosperity. Often, the person in search of health has no clue of the trap that has been laid for him or her. Rather than speaking for the weak; rather than fighting for their rights to get full healthcare services, the spiritual leaders play around with their innocence through spiritual gullibility.

The tragedy of sanctity is well exhibited in how we weaken sanctity through various systems and polices that various countries have embraced by the way we treat the weaker, the enemy, the disabled, the strange, the unborn, the poor, the ex-friend, that racial other, the ethnic other, or whomever else we find difficult to include within the community of the true human. Since countries have spelt out their given constitutions and policies (often skewed towards the rich) that scorn at these groups, the spiritual real realm is full of spiritual gullibility as, to some individuals, this is the only avenue to seek solace for their troubled souls. 
With spiritual gullibility in such times as presented by the COVID-19 pandemic or other healthcare crises, sanctity can no longer be only the defending, protecting and respecting the dignity of human life, it should also be about those things that done in the name of God, in the name of spirituality and how they undermine one person's health. Spiritual gullibility is now a game that if one is not careful, it is perpetrated by individual religious leaders, institutions and even governments. Worse, spiritual gullibility is manifested also through individual decisions regarding lifestyles people choose, eating habits, sexual preferences one has, all of these tragedies of sanctity.

At times, some moral arguments are presented to contend the notion that sanctity is just a free ticket to defending, protecting and respecting human life. On the other hand, it is important to note that the tragedy of sanctity is now as a result of personal responsibility for health. For example, an individuals' lifestyle, eating habits, whether or not they smoke, the dangerous pastimes or sports they indulge in, the danger of not indulging in any sports; hence becoming unfit and obese, the sexual preferences one has and the frequency with which one indulges them and with whom and with what care, are all arguably reasonable bases for the tragedy of sanctity.

Spiritual gullibility threatens the sanctity of life, as those who engage in it only aim at what they are likely to get. They are not interested to know where their adherents live. Some live in informal settlements or in very dangerous, overcrowded and polluted areas; yet their religious leaders establish tent ministries or temporary religious shelters for spiritual gullibility activities. These adherents have to travel long distances to attend spiritual activities proposed to them. Unfortunately, some in search of health in the form of prayers and miracles face difficulties to make little income that is required by their spiritual leaders. This is where spiritual gullibility threatens the sanctity of life, because many who practise it are driven by selfish ambitions, selfish desires and self-gain. These undermine the sanctity of life, especially when in search of health.

While in many African countries the health of its people is often determined by how governments structure healthcare services, spiritual healers continue to take centre stage. So, while professional medics exist, indigenous and spiritual healers are on the increase. Almost every Christian church holds healing services. Spiritual gullibility is elaborated by Paul Gifford (1998: 335), observing that the Church's teachings on faith and lately emphasis on prosperity theology, which 'is preached at length in the newer churches, and 
these beliefs are ritually enacted with collections and offerings. They are reinforced by countless testimonies'. He continues to argue that 'for church leaders this faith teaching is obviously very functional for it brings revenues that enable them to survive and flourish in a very competitive field'. But the conditions of the poor, as well as low incomes, the worsening climate change and the increasing numbers of the unemployed, and now the effects of COVID19 pandemics, all increase the desire for faith healings; hence the avenues for spiritual gullibility being exercised. The greatest injustices in respect of health are reflections of unjust social inequalities in accessing healthcare for all, as espoused in the social policy on health.

\section{Situating the Tragedy of Scarcity}

We live in a generation that is faced at the same time with tremendous opportunities and risks. We note that COVID-19 has exposed the weaknesses of spiritual gullibility, as many sacred places were forced into lockdowns and religious activities got limited to individuals' respective homes. However, more importantly, we must face scarcity and address its ugly face. Are we in the era where scarcity literally poses a danger to all of those in search of health? Is it possible that doctors, healthcare institutions and spiritual healers literally have an opportunity to practise unethical decisions by choosing patients? Spiritual gullibility is practised among our peoples by the indigenous and spiritual healers as they seek those who can pay for the service. We are pretty sure indeed that where scarcity prevails, those who lack and, or, seek treatment are likely to miss out, while others are likely to be condemned to an early death. Scarcity may also be comparative, where patients have to be prioritized based on their income, ethnicity, religious affiliation or insurance coverage.

For some, scarcity of resources for healthcare is a permanent and inescapable condition. At times, spiritual gullibility surfaces whenever patients are unable to raise funds for healthcare. In most cases, the family and communities pull together to raise medical funds, or at most, seek indigenous and faith healings, even though the latter is taken as the last resort. Indeed, scarcity is a curse for some, and only a push to spiritual gullibility. At times, healthcare conditions push the victims to consider spiritual gullibility as an option for eliminating suffering that is effected by scarcity.

Many people faced with the tragedy of scarcity have been haunted by most health systems that have increased costs, making the poor more vulne- 
rable. Most government ministries or departments of health in African countries lack the necessary equipment or personnel to offer quality services. Therefore this sends the poor to spiritual alternatives. Many hospitals continue to struggle with structural systems and diminishing equipment; medical professionals are more often on strike or in private practice, which are not accessible to the poor. This kind of scarcity allows spiritual gullibility to prey on many innocent people.

Often, whether in urban or rural areas, those whose claim of well-being is attributed to some kind of indigenous or spiritual healing are used as mouthpieces to market their leaders. One will find their denominations or ministries are swelling with adherents from one week or month to another. Hence, many people driven to the tragedy of scarcity tend to keep moving from one practitioner to another, making spiritual gullibility a continuum for the perpetrator and the victims.

Does the notion or suggestion that the best we can do is to increase supply and make scarcity a nil to those in search of health? Does supply increase or reduce spiritual gullibility? During the HIV and AIDS crisis, and now the COVID-19 global pandemic, we have heard the calls to produce more personal protective equipment, or the rush for vaccine development. What else can we manufacture? How many more calls for blood donations can we make? Should we invest in training more medical professionals, and does this in any way reduce the cost of medical care in any way? Not necessarily. In fact, medical care is costly, and is becoming costlier still; hence making it almost an illusion to all those in search of health. In essence then, even if we increase the supply of all that counts to health, it does not eliminate all factors that enhance scarcity. Consequently, resource provision in circumstances of scarcity in healthcare creates hard choices for individuals, families, and societies; a platform for spiritual gullibility to take place.

\section{Attending to the Tragedies of Sanctity and Scarcity}

Spiritual gullibility is a crisis that confronts medicine with such tragic choices in different ways as people make uninformed decisions. In decision making, there are two strategies for denying the conjoined tragedies of sanctity and scarcity: One is to deny sanctity; the other is to deny scarcity. Spiritual gullibility argues that sanctity is the basis of operations and scarcity is what it will provide. However, spiritual gullibility chooses the patients to be attended 
to with clear plans to finance them, whether in the form of money or in kind. Spiritual gullibility demands healing tithes, offerings or even animals or food. The victim is compelled to value his or her life from understanding that he or she is responsible for his/her well-being. Hence life is valued on the basis of one's contribution. While society seems to push the idea that suffering from ill-health can only be treated by health financing, even spiritual gullibility seems to offer the same fate. This is why it is important to rethink ways and means to ensure that all the needy members of our society are supported in their search for health. As Verhey (1998: 976) argues,

to provide ordinary healthcare to the wealthy because they can pay or to the nice because we like them or to the promising because of their social utility while we withhold it from the poor, the outcast, and the handicapped is not only tragic but unjust.

I wish to add that to celebrate the conspiracy of silence in many of our African contexts while spiritual gullibility undermines the poor and exploits the innocent is not only a denial to love one another as created in the image of God, but it is a perpetuation of injustice in the name of spirituality. The imbalance this creates in society must be denounced in the strongest terms possible, as new strategies are laid to uplift the poor and the vulnerable among God's people.

During COVID-19, we now note the true reality where in some contexts scarcity has come to the fore. Since sanctity demands that each patient is created in the image of God, we have come to see what Verhey (1998: 975) proposes, namely that 'we must limit what we would for at least some patients' to becoming a reality as pressure amounts on who should access ICUs or HDUs during the COVID-19 pandemic. This is even made worse, as some areas on the African continent do not have even such facilities. No wonder spiritual gullibility reigns in such circumstances, as people tend to incline towards that which they can access easily, and for many, spirituality is an easy avenue to address ill-health.

Spiritual gullibility has played out that it is a divine activity; yet it is taking advantage of the poor and innocent, because government ministries have not allocated enough resources to ensure the enhancement of the wellbeing of all people. There are no free medicine or free medical camps. But spiritual gullibility offers morning glory services for healing: midweek health 
restoration services; deliverance special prayers; weekend-long exhortation healing journeys; or mountain-top healing adventures. Then the argument advanced here is correct, namely that,

if it is sanctity which makes allocation decisions necessary, it is scarcity which makes them tragic. For when the goods or services to be allocated are good or services on which life or health may depend and when the unbounded love for God for each one requires that we regard each life as equal value, then the necessary allocation decision ins necessarily tragic (Verhey 1998: 975).

Spiritual gullibility will remain with us for many years to come, because, in search of health, we have chosen to offer our souls to the highest bidder! If scarcity of resources cannot allow one to stop at the pharmacy to get some basic medicines, spiritual gullibility will pull one towards prayers for sale as payments for sale (as payments can be made later or in kind). We must stop and resist the use of classism in search of health. We must fight to ensure that all people on the continent have access to good healthcare services and that the indigenous and indigenous and spiritual healing practices are not hijacked by spiritual gullibility. We must fight all the barriers that may make access to health services impossible, whether those barriers are corruption, nepotism, economics, geographical, political affiliation, gender, creed or social status.

Spiritual gullibility is extended each day, because the practitioners argue that their services are in high demand. In other words, both tragedies of sanctity and scarcity are epitomes of spirituality, because the practitioners are governed by the desire for power and profit. For sure, the imbalance between sanctity and scarcity is made worse when one keeps in mind that those who have the resources will access the services (even though the COVID-19 pandemic has shown us otherwise), or those who have medical insurance can easily access services, while poorer people are increasingly faced with weakness and poverty.

We must understand that the conjoined twins of sanctity and scarcity tragedies have presented a humanitarian crisis in healthcare, since it has created an identity crisis. Consequently, healthcare must be seen beyond finances. Healthcare must remain centred on caring, consequently, those in authority whether in government, church or non-governmental organizations must embrace the values of integrity and character that accompany their activities 
and avoid the commodification of healthcare services. The services must not be based on who can afford to pay. Otherwise the search for health will remain the domain of the rich, the powerful and the spiritually gullible, while the poor watch, lament and pray. Unfortunately, this has become a continuum in many contexts in various African countries.

Piety must call the health practitioners and church leaders, and those with reason must engage in a discourse aimed at removing in search of health for the marketplace. We should not allow human lives to be on sale for the highest bidder in search of health. It is evil to watch and see spiritual gullibility being played among those who cannot afford to pay for health services. Efforts must be made to secure the sanctity of such lives. The Church must stand up and be counted on the side of life and not in solidarity with forces that enhance evil and death in the form of spiritual gullibility. The Church must seek to proclaim the message of freedom in Luke 4:18, the poor, the sick, the oppressed and the blind. Whether these people are in the church already or in the society, Jesus came for such people!

In order for us to overcome spiritual gullibility, there has to be intentional public policy that moves healthcare away from profit. As long as healthcare is considered a revenue-generating service, human beings will continue to suffer. The church-related and -run hospitals are now mostly accessible by the rich only, the poor cannot access them. Most of these hospitals - both government and church-related - lack medicines, but the expensive and private, individually owned hospitals have their expensive pharmacies stocked with all kinds of medicines. This imbalance must be addressed urgently. The profit motif in healthcare must be brought to the fore as a burden for the majority poor and continues to undermine the sanctity of life, as the poor are pushed to the periphery of spiritual gullibility.

The Church must embrace the spirit of caring for one another.

No matter the consequences, African peoples in their cultures continue to resist extreme individualism, which degrades and fragments African values of well-being and undermines the essence of a humane setting (Mageto 2006: 5).

It is important for the Church to be aware that governments are discriminating against its own people, and the open space is an avenue for spiritual gullibility which undermines its members. 
Spiritual gullibility seems to suggest that scarcity is a necessity, as the sick must be attended to. Scarcity also demands that a Godly image must be projected by all means necessary. We must be reminded by John Wesley's demand, 'Do all the good you can, by all the means you can, in all the ways you can, in all the places you can, at all the times you can', which is a true sign of loving God and loving one another.

Every life is necessary. Every life must be treated with the dignity it deserves, whether we place a financial value it or not. Going back to our Ubuntu values, spiritual gullibility is a capitalistic practice that must not be intertwined in the continent of Africa. We must cherish relationships of trust and truthfulness. This can only be achieved if we embrace Oden's (2007: 29) call that 'it remains the task of a generation of future scholars, many of them from Africa, to study the flow of ideas from Africa to Europe and to better describe their impact'.

If alternative healthcare services are to be provided in the community, then the church must be at the forefront to condemn unjustified exploitative, expensive and unreachable healthcare services governments have put in place. At the same, the Church must condemn those among them and outside the church who utilize spiritual gullibility to offer prayers for sale as the sick seek faith-healing services. In essence then, the Church must look for ways to embrace less health-costly ways to help many others access health services and, at the same time, sensitize communities to attend to the threats to human life emanating from the kinds of lifestyles we choose in this generation.

\section{Conclusion}

It is unfortunate that from East to West, from the North to the South of the continent of Africa, many in the populace are in search of health. In their search, they are faced with the two tragedies, scarcity and sanctity, which will remain with us forever. Even with the latest health technological advances, the majority poor who are unable to access healthcare services cannot remain vulnerable and be preyed upon by those who engage in spiritual gullibility.

We must overcome spiritual gullibility in healthcare. This can only become possible through concerted efforts, especially among faith-based communities. Commodifying healthcare services provides opportunities to evildoers driven by spiritual gullibility to continue to prey upon the vulnerable. The body of Christ, the Church, must be at the forefront to denounce their own 
who are now driven by individual capitalistic tendencies to exploit the sick poor. God demands that since human beings are created in the image of God, we must embrace strategies to coalesce resources and human efforts to ensure the well-being of all people. And as the COVID-19 pandemic has shown us, no matter the kind of resources or wealth accessible to you, integrity demands that we must value human life more than anything else. Integrity demands that we must embrace ways and means to balance the conjoined tragedies of sanctity and scarcity for the well-being of the young and the old. We must change the spiritual paradigms that perpetuate and exploit the sick poor in the name of spiritual healing through manipulative spiritual gullibility as prayers for sale are on the increase and more people become vulnerable each month or year. So, let us act with integrity!

\section{References}

Barth, K. 1998. The Will to be Healthy. In Lammers, S.E. \& A. Verhey (eds.): On Moral Medicine: Theological Perspectives in Medical Ethics. Grand Rapids, Michigan: WM. B. Eerdmans Publishing Co.

Bohannan, P. 1964. Africa and Africans. Garden City, NY: The Natural History Press.

Gifford, P. 1998. African Christianity: Its Public Role. Bloomington and Indianapolis, IN: Indiana University Press.

Haule, C. 1969. Bantu 'Witchcraft' and Christian Morality: The Encounter of Bantu Uchawi wth Christian Morality - An Anthropological and Theological Study. Schonek-Beckenried: Nouvelle Revue de Science Missionnaire.

Kunhiyop, S.W. 2008. African Christian Ethics. Nairobi, Kenya: Hippobooks. Magesa, L. 1997. African Religion: The Moral Traditions of Abundant Life. Maryknoll, NY: Orbis.

Mageto, P. 2006. Victim Theology: A Critical Look at the Church's Response to AIDS. Bloomington, IN: Authorhouse.

Mbiti, S.J. 1969. African Religions and Philosophy. London: Heinemann.

Oden, T.C. 2007. How Africa Shaped the Christian Mind: Rediscovering the African Seedbed of Western Christianity. Downers Grove, Illinois: IVP Books.

Omonzejele, F. Peter 2008. African Concepts of Health, Disease, and Treat- 
ment: An Ethical Inquiry. EXPLORE: The Journal of Science and Healing 4,2: $120-126$.

https://doi.org/10.1016/j.explore.2007.12.001

Verhey, A. 2012. Sanctity and Scarcity: The Making of Tragedy. In Lammers S.E. \& A. Verhey (eds.): On Moral Medicine: Theological Perspectives in Medical Ethics. Grand Rapids, Michigan: WM. B. Eerdmans Publishing Co.

World Health Organisation 1998. Health Promotion Glossary. Geneva: World Health Organisation.

Professor Peter Maiko Mageto Deputy Vice-Chancellor Africa University magetop@africau.edu 